学会賞受賞論文

\title{
胎児発育および適切な胎盤の酸素化における母体赤血球の ENT1 による 酸素供給の重要性 Maternal erythrocyte ENT1-mediated oxygen delivery is necessary for adequate placental oxygenation and fetal growth
}

Seisuke Sayama ${ }^{1 \& 2}$, Anren Song ${ }^{1}$, Benjamin C. Brown ${ }^{3}$, Jacob Couturier ${ }^{4}$, Takayuki Iriyama ${ }^{2}$, Baha Sibai ${ }^{5}$, Rodney E. Kellems ${ }^{1 \& 6}$, Angelo D'Alessandro ${ }^{3}$ and Yang Xia ${ }^{1,6}$

Department of Obstetrics \& Gynecology, University of Tokyo, Japan

7-3-1 Hongo, Bunkyo-ku, Tokyo, Japan

1) Department of Biochemistry and Molecular Biology,

2) Department of Obstetrics \& Gynecology, University of Tokyo, Japan,

3) Department of Biochemistry and Molecular Genetics, University of Colorado School of Medicine, Aurora, CO, USA,

4) Department of Internal Medicine,

5) Department of Obstetrics \& Gynecology, The University of Texas Health Science Center at Houston, Houston, TX, USA,

6) Graduate School of Biomedical Sciences, University of Texas Health Science Center at Houston, Houston, TX, USA

キーワード:

胎盤形成不全、胎児発育不全、赤血球、Hypoxia inducible factor 1- $a(H I F-1 a)$ 、アミノ酸トランスポーター、

Large neutral amino acid transporter 1 (LAT1)

Correspondence:

Seisuke Sayama

Department of Obstetrics \& Gynecology, University of Tokyo, Japan

7-3-1 Hongo, Bunkyo-ku, Tokyo, Japan

Tel: 03-3815-5411

E-mail: sayamas-gyn@h.u-tokyo.ac.jp

Received 2020/10/04

Accepted 2020/10/28

要 旨

【目的】低酸素と胎盤形成不全の関連は知られているが、低酸素において中心的な役割を担う赤血球の機 能低下と胎盤形成不全との関連に関する知見は極めて少ない。本研究では、赤血球の膜上に存在する核 酸トランスポーターである Equilibrative nucleoside transporter 1（ENT1）をノックアウトしたモデル マウスを用いて、母獣赤血球の酸素運搬能が低下した際に認める表現型を検証し、その分子学的背景も 検討した。

【方法】施設内研究倫理委員会承認の下、上記モデルマウスの赤血球酸素運搬能が低下していることを 
確認すると同時に、妊娠における表現型が胎児発育不全であることを確認し、メタボロミクス解析 を用いて、母獣からの胎盤へのアミノ酸取り込みが低下しているを同定した。胎盤局所での Hypoxia inducible factor $1-\alpha$ (HIF-1 $\alpha$ ) の発現を免疫染色法で検討し、realtime RT-PCR 及びウエスタンブ ロット法により、胎盤でのアミノ酸トランスポーターの発現を検討した。最後に絨毛細胞セルライン、 HTR-8/SVneo を HIF-1 $\alpha$ 安定甋である Dimethyloxaloylglycine（DMOG）と共培養することで、HIF-1 $\alpha$ とアミノ酸トランスポーター発現の関連についても検証した。

【成績】赤血球酸素運搬能が低下した遺伝子改変マウスでは、胎盤局所での HIF-1 $\alpha$ の発現の上昇を認 め、胎盤での Large neutral amino acid transporter 1 (LAT1) の発現が低下していた。また、HTR-8/ SVneo 細胞培養において HIF - $1 \alpha$ 発現下では LAT1 の mRNA 低下を認めた。

【結論】母獣の赤血球酸素運搬能が低下することで胎盤局所での HIF - $1 \alpha$ 発現が充進し、胎盤での LAT1 の発現が低下することで母体循環中の血清からのアミノ酸の取り込みが低下し、胎児発育不全の表現型 を呈し得ることが示唆された。

\section{1) 緒言}

妊娠初期の胎盤形成障害は、胎盤での低酸素を 惹起し、胎盤機能不全に伴う産科疾患である胎児 発育不全 (Fetal growth restriction: FGR) や妊娠 高血圧腎症（Preeclampsia: PE）の病態に深く関 与していることが知られている。赤血球は酸素運 搬に関わる最も重要な「臓器」ともいえるが、赤 血球の機能と FGR や PE との関連を示した報告は 極めて少ない。

赤血球は体内で唯一酸素を運搬する細胞である と同時に、未梢組織での低酸素を感知する能力も 備えている。周辺環境に適応するために赤血球 は自身の酸素運搬能を修飾する機能を有してお り、酸素とへモグロビンの親和性を調整するこ とでその酸素運搬能を調整している。その調整 機構で最も中心的な役割を果たしているのが 2 , 3-bisphosphogylcerate（2, 3-BPG）であり、赤 血球内で解糖系により生合成される。赤血球の 酸素運搬能は、酸素がへモグロビンの 50 \% 結合 飽和するときの酸素分圧である $p 50$ で評価され、 $p 50$ は 2, 3-BPG と正の相関を示し、p50 及び 2, 3-BPG は酸素運搬能と正の相関を示す。1990 年に、胎児発育不全症例の母体の 2, 3-BPG 及び p50 は正常の胎児発育の母体と比較して有意に低 值を示していたがその分子機序を同定するには至 らず、この赤血球の酸素運搬能の低下が如何にし て FGR をきたすかは不明であった ${ }^{[1]}$

高地などの低酸素ストレスに赤血球が対応する 機序は、赤血球の膜上に存在する核酸トランス ポーターである ENT1 が、低酸素ストレスによっ て増加した細胞外のアデノシンを取り込み、酸素
運搬能を上昇させるという調節機構が行われるこ とで低酸素に応答する ${ }^{[2]}$ 。赤血球から ENT1 を除 去すると低酸素応答に障害をきたすと考えられる ため、本研究では、ENT1 を母獣赤血球からノッ クアウトし、その妊娠における表現型を検証し、 その分子機序の解明も行なった。

\section{2 ) 材料および方法}

テキサス大学の倫理委員会の承認を経た後、 lox-Cre system を用いて、母獣の赤血球の ENT1 のみを除去したコンディショナルノックアウトモ デルマウス、Ent1 1lox/flox EpoR-Cre ${ }^{+}(\mathrm{E} 1 \mathrm{FE})$ を作 成し、その妊娠における表現型を検証した。コン トロール郡はEpoR-Cre P $\left.^{+} \mathrm{EPO}\right)$ を用いて、共に wild type の雄と交配させることで、両群の唯一 の違いは E1FE 群での母獣赤血球の ENT1 が久損 しているという交配モデル（Fig. 1) を作成した。 胵プラグを確認した日を妊娠 0.5 日とし、妊娠 13.5、15.5、17.5 日で tail cuff 法での血圧測定を 実施し、妊娠 18.5 日で ELISA による蛋白尿測定、 採血、解剖、胎盤重量、胎仔の体重の測定を行なっ た。

p50 及び 2, 3-BPG の測定、メタボロミクス解 析などは以前の報告と同様の方法で行なった ${ }^{[3]}$ 。

統計学的解析は、Prism 5 software 用いて EPO 群と E1FE 群を比較して Student's t testを用 いた。P<0.05を統計学的有意差ありと判断した。 


\section{Transgenic mouse \\ ENT1 exclusively deleted from maternal RBC}
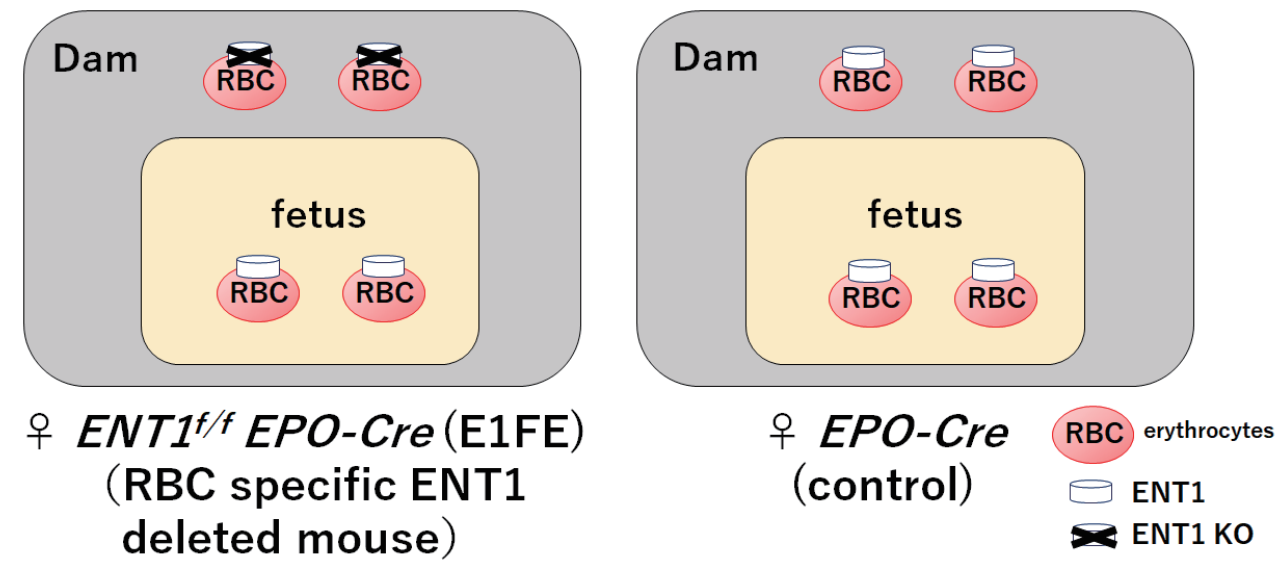

Fig. 1 母獣の赤血球の ENT1 のみを除去したコンディショナルノックアウトモデルマウス、Ent 1 flox/flox EpoR-Cre+(E1FE) を実験モデルとして使用する。Wild type の雄と交配することで、胎仔の flox は全て flox/ wild typeになるため、胎仔はCreには影響されない。Cre 自体が表現型を有する可能性があるため、母獣の コントロールには EPO-Cre を使用することで母獣の赤血球の ENT1 を除去した影響のみを検証できる交配モ デルを確立した。
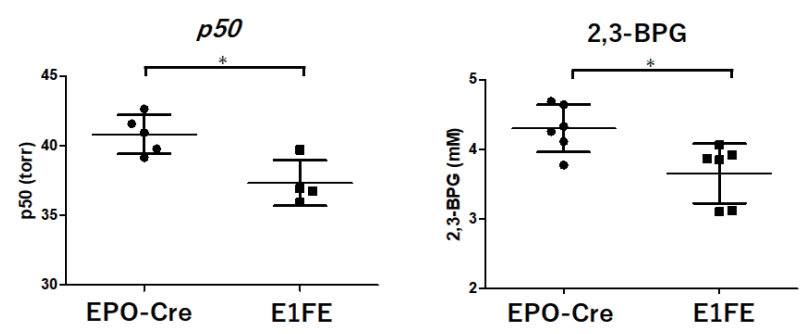

Fig. 2 E1FE 及び EPO の妊娠18.5日での赤血球の $p 50$ 及び 2, 3-BPG を 測定したところ、EPO 群と比較して E1FE 群で $p 50$ 及び 2,3BPG 共に有意に低下しており、これは E1FE の母獣の赤血球酸 素運搬能が低下していることを示している（*P< ${ }^{*} 0.05 ） 。$

\section{3 ) 結果}

(1)E1FE 群は $p 50$ 及び 2,3-BPG の低下を認め、 FGR の表現型を呈する

まず、 $\mathrm{E} 1 \mathrm{FE}$ 及び $\mathrm{EPO}$ の妊娠 18.5 日での赤血 球の $p 50$ 及び 2, 3-BPG を測定したところ、EPO 群と比較して $\mathrm{E} 1 \mathrm{FE}$ 群で $p 50$ 及び 2, 3-BPG 共 に有意に低下しており、これはE1FEの母獣の 赤血球酸素運搬能が低下していることを示して いる (Fig. 2)。それに伴い、胎盤での Hypoxia inducible factor $1-\alpha(\mathrm{HIF}-1 \alpha)$ の発現を蛍光免疫 染色で検証したところ、EPO 群と比較して E1FE 群の spongiotrophoblast での HIF - $1 \alpha$ の発現六進 を認め、赤血球の酸素運搬能の低下が胎盤局所で の低酸素を惹起していることを示していた。ま た、E1FEの妊娠における胎盤形成不全の表現型 を呈するかを検証するために EPO 群と E1FE 群 の母獣の蛋白尿、血圧、胎仔の重量を測定したと ころ、E1FE 群で有意に胎仔の体重低下を認めて いたものの、蛋白尿や高血圧は認めず、PEでは なくFGRの表現型を呈していることが示された (Fig. 3)。

\section{(2)E1FE の胎盤ではアミノ酸濃度が低いが、 母獣血清中のアミノ酸濃度は高い}

FGR をきたす背景に存在する代謝経路を同定 するために、EPO 群及び E1FE 群の母獣の血清及 び胎盤でのメタボロミクス解析を行なった。する と、ほぼ全てのアミノ酸に関して EPO 群と比較 して、E1FE 群の胎盤で低值、血清で高值を示し ており、FGRの表現型をきたす背景に母獣から胎 盤へのアミノ酸の取り达み阻害の存在が示唆され た (Fig. 4)。

Reproductive Immunology and Biology Volume 35 • Number 1 • November 2020 Japan Society for Immunology of Reproduction 

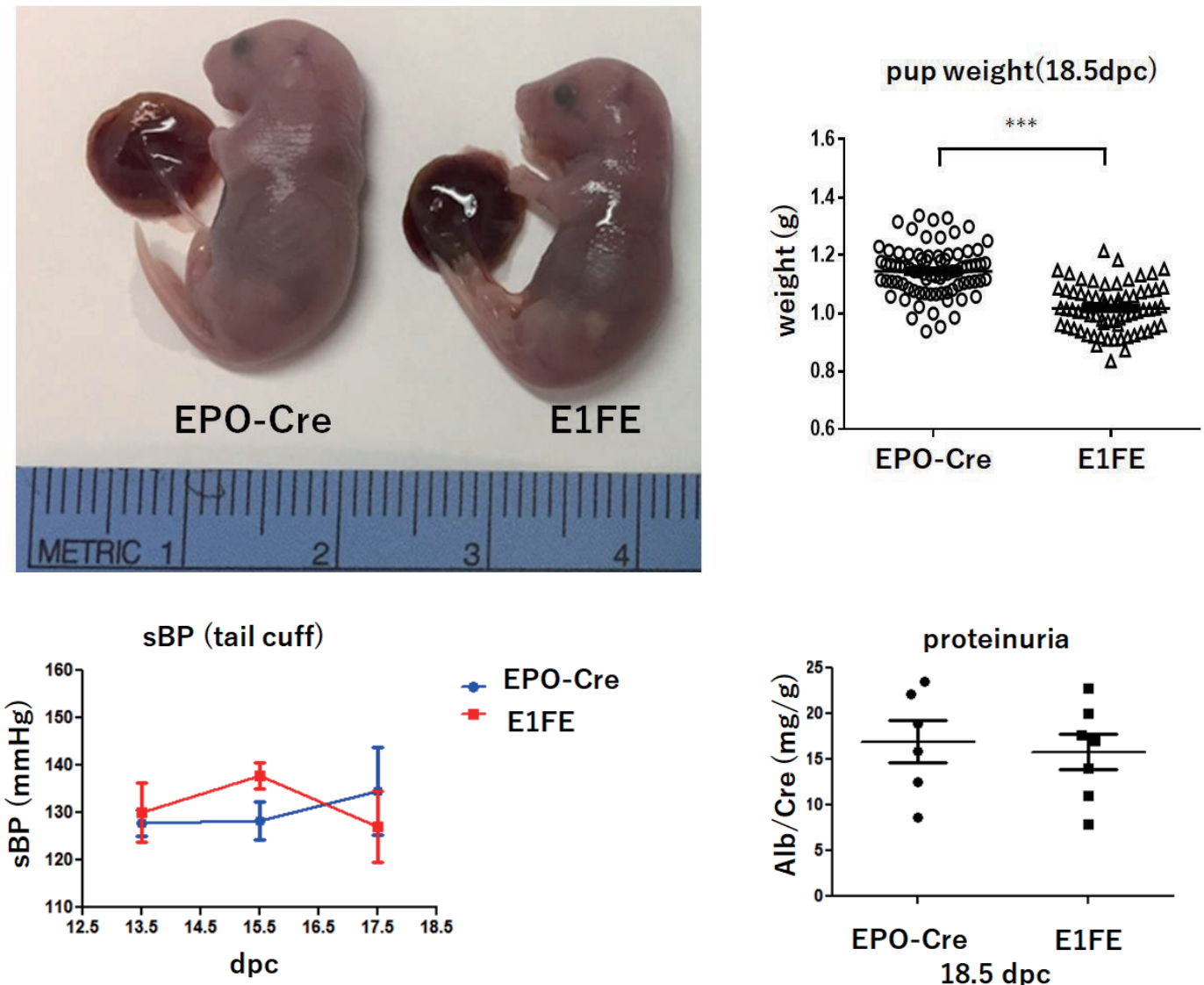

Fig. 3 E1FE の胎仔は EPO と比較して有意に体重が低かった（A， B ）が、血圧（C）と蛋白尿は両群間で有意差は認めず、 E1FE はFGR の表現型を有することを確認した。

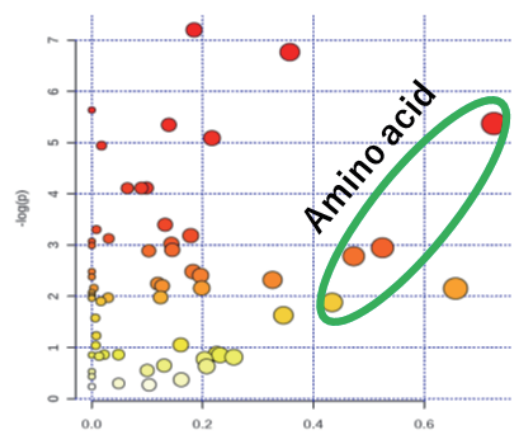

Placenta
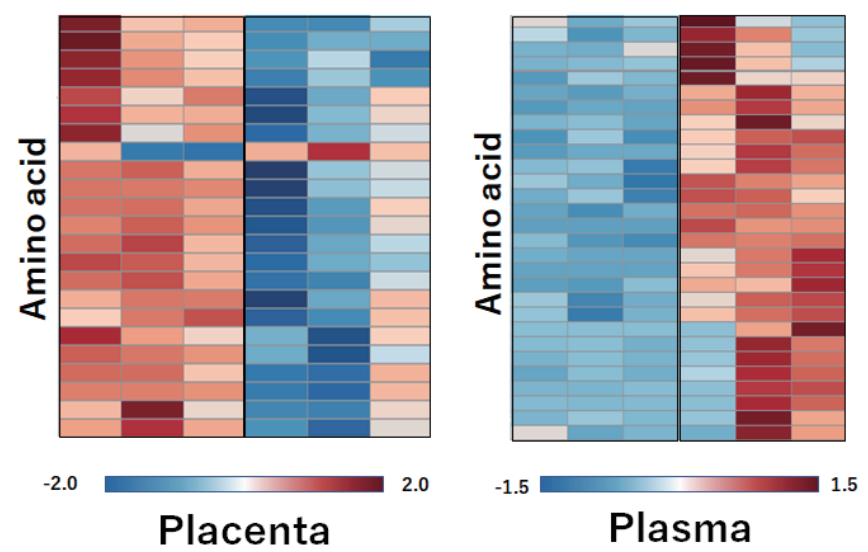

Fig. 4 胎盤におけるメタボロミクス解析でEPO とE1FE を比較したところ、アミノ酸代謝に関わる経路が強く影響を受けていた（A）。 胎盤及び血清のアミノ酸の代謝を検証したところ、EPO と比較して E1FE ではほぼ全てのアミノ酸において胎盤で低下してお り、血清中で増加を認めた（B)。 

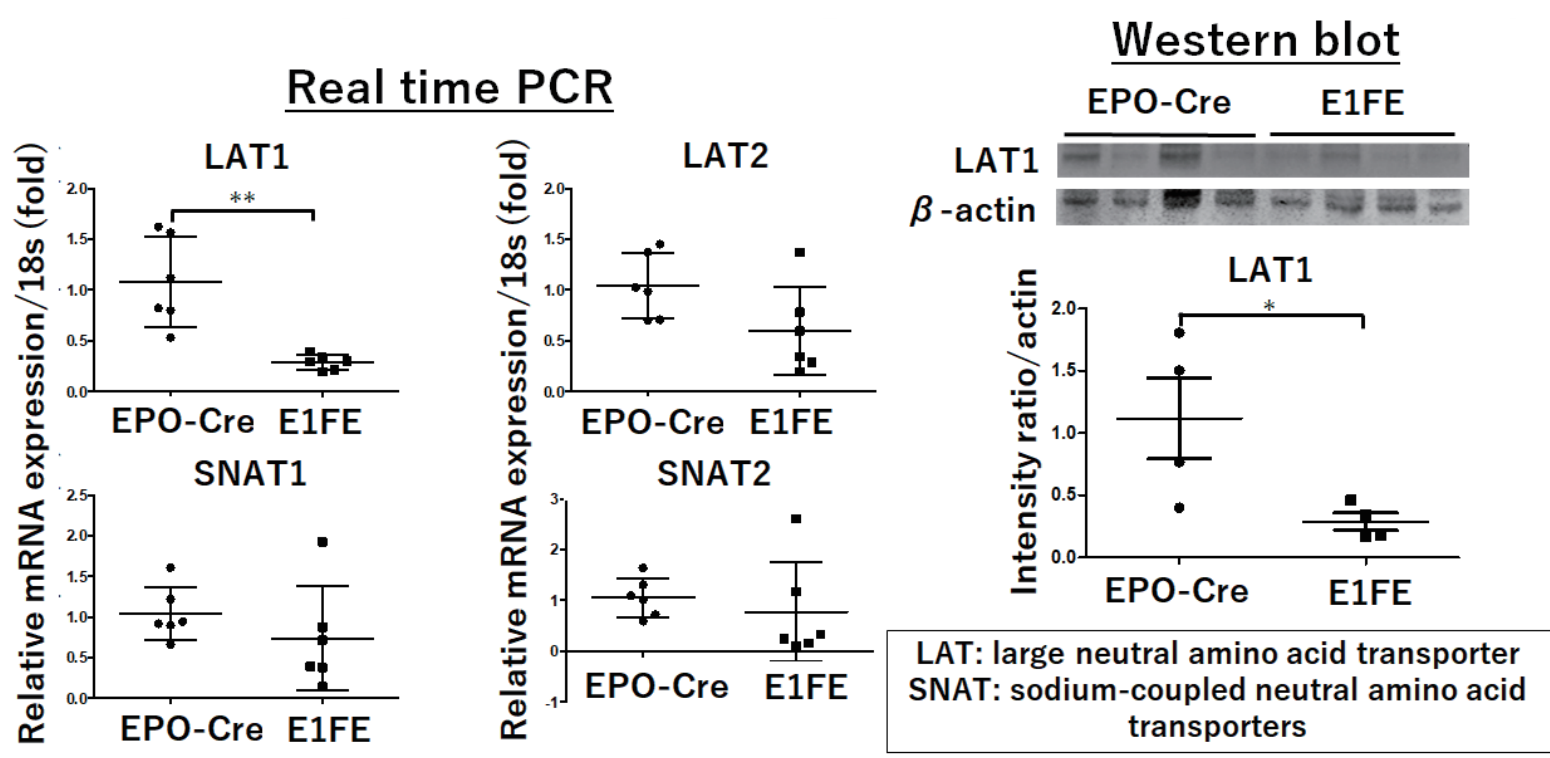

Fig. 5 EPO 及びE1FE の胎盤での主要なアミノ酸トランスポーターの発現を realtime RT-PCR で検証したところ、EPO と比較してE1FE にお いて、LAT1の mRN Aが有意に低下していた（A）。タンパクレベルでの発現も低下していることをウエスタンブロット法で確認した (B)。( $\left.{ }^{*} \mathrm{P}<0.05,{ }^{* *} \mathrm{P}<0.01\right)$

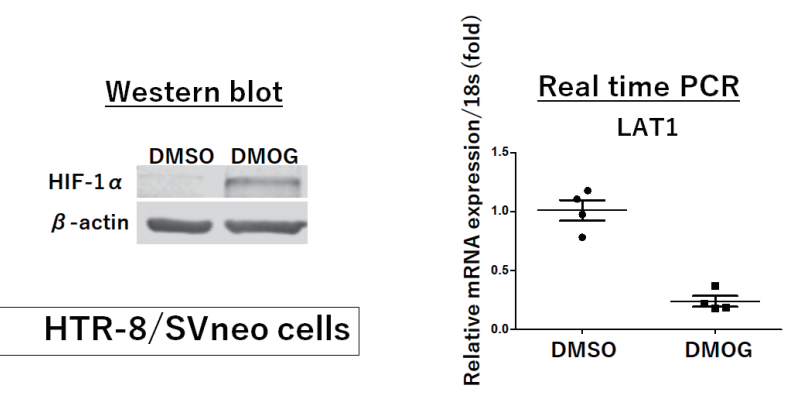

Fig. 6 HTR-8/SVneo 細胞をDMOG 存在下で培養すると、HIF-1aの 発現が安定化される $(A)$ 。DMOG 存在下で LAT1 の mRNA を RT-PCR で検証すると、非存在下と比較して、有意にLAT1 の mRNA が低下していることが示された $(B) 。(* * * P<0.005)$

\section{(3)E1FE の胎盤では Large neutral amino acid} transporter 1 (LAT1) の mRNA 及びタンパク 発現が低下している

母獣からのアミノ酸取り込みにおいて中心的な 役割を担うのが胎盤でのアミノ酸トランスポー ターであるため、EPO 群及び E1FE 群での胎盤で の主要なアミノ酸トランスポーターの mRNA を realtime RT-PCR を用いて比較したところ、EPO 群と比較して E1FE群の胎盤において LAT1の mRNA が有意に低下しており、ウエスタンブロッ
トでも同様の結果が確認され、EPO 群と比較し て E1FE 群の胎盤での LAT1 タンパクの発現低下 を認めた（Fig.5）。

(4)HTR-8/SVneo 細胞で HIF-1 $a$ を安定化させる ことで LAT1 の mRNA が抑制される

胎盤局所での低酸素と胎盤での LAT1 の発現低 下との関連を検証するために、HIF-1 $\alpha$ の安定剂 である Dimethyloxaloylglycine (DMOG) 存在下 で絨毛細胞セルライン、HTR-8/SVneo 細胞を培 養し、LAT1 の mRNA を realtime PCR 用いて検 証した。DMOG 存在下では非存在下と比較して LAT1 の mRNA は有意に低下していた（Fig. 6)。 よって、胎盤での LAT1 発現低下の背景に胎盤局 所での HIF-1 $1 \alpha$ の発現上昇があることが示され た。

\section{4 ) 考察}

本研究では以下を明らかとした

(1)母体赤血球の酸素運搬能の低下が胎盤局所での HIF - $1 \alpha$ 発現上昇を惹起する。

(2)胎盤での HIF- $1 \alpha$ の発現㠵進は胎盤での LAT1 の発現低下をきたし、母体から胎盤へのアミノ 
酸取り込みを阻害することで FGR の表現型を きたす。

1990 年に FGR 症例の母体から採取した赤血 球の $p 50$ 及び $2,3-\mathrm{BPG}$ が低下、すなわち酸素運 搬能が低下していることが示された ${ }^{[1]}$ が、赤血 球の酸素運搬低下が FGR をきたす分子機序は未 解明であった。本研究により、母体の赤血球酸 素運搬能の低下が胎盤局所での低酸素を惹起し、 HIF - $1 \alpha$ の発現を六進させ、胎盤のアミノ酸トラ ンスポーターの発現を低下させるという機序をマ ウスモデルで示すことができた。ヒトとマウスで は胎盤の構造が違うが、母体赤血球の酸素運搬能 が低下している症例では同様の機序により FGR をきたしている可能性があり、これまで注目され ていなかった側面から FGRの病態生理へのアプ ローチが可能となった。これによって、新たな治 療戦略の可能性も拓け、母体赤血球をターゲット とした FGRの治療、ひいては胎盤形成不全とい う意味では類似の疾患である PEへの応用も可能 であると考えられる。今後は、このような視点か ら FGR 及び PEの新たな治療戦略を確立すること を目標とする。

\section{5）謝辞}

本研究を遂行するにあたり、御指導御鞭撻を賜 りましたテキサス大学の Yang Xia 教授、Rodney Kellems 教授、Baha Sibai 教授、コロラド大学 の Angelo D'Alessandro 助教、東京大学医学部 産科婦人科学教室の入山高行講師に深く感謝 の意を表します。また、テキサス大学の Jacob Couturier 助教にはフローサイトメトリーの測定、 Anren Song 助教にはウエスタンブロットでの御 支援、御指導をいただきました。コロラド大学の Benjamin Brown 助教にはメタボロミクス解析で の御支援、御指導をいただきました。この場を借 りて深い謝意を表します。

\section{6) 引用文献}

1 ) Brown, E.G., et al., 1990. The relationship of maternal erythrocyte oxygen transport parameters to intrauterine growth retardation. American Journal of Obstetrics and Gynecology, 162(1): p. 223-229.

2 ) Song, A., et al., 2017. Erythrocytes retain hypoxic adenosine response for faster acclimatization upon re-ascent. Nature Communications, 8: p. 14108-14108.

3 ) Sayama, S., et al., 2020. Maternal erythrocyte ENT1-mediated AMPK activation counteracts placental hypoxia and supports fetal growth. JCI insight, 5(10): p. e130205. 


\title{
Maternal erythrocyte ENT1-mediated oxygen delivery is necessary for adequate placental oxygenation and fetal growth
}

\author{
Seisuke Sayama ${ }^{1 \& 2}$, Anren Song ${ }^{1}$, Benjamin C. Brown ${ }^{3}$, Jacob Couturier ${ }^{4}$, Takayuki Iriyama ${ }^{2}$, \\ Baha Sibai ${ }^{5}$, Rodney E. Kellems ${ }^{1 \& 6}$, Angelo D'Alessandro ${ }^{3}$ and Yang Xia ${ }^{1,6}$ \\ 1) Department of Biochemistry and Molecular Biology \\ 2) Department of Obstetrics \& Gynecology, University of Tokyo, Japan \\ 3) Department of Biochemistry and Molecular Genetics, University of Colorado School of Medicine, \\ Aurora, CO, USA \\ 4) Department of Internal Medicine \\ 5) Department of Obstetrics \& Gynecology, The University of Texas Health Science Center at Houston, \\ Houston, TX, USA \\ 6) Graduate School of Biomedical Sciences, University of Texas Health Science Center at Houston, \\ Houston, TX, USA
}

Department of Obstetrics \& Gynecology, University of Tokyo, Japan

(7-3-1 Hongo, Bunkyo-ku, Tokyo, Japan)

Correspondence to: Seisuke Sayama

Department of Obstetrics \& Gynecology, University of Tokyo, Japan

7-3-1 Hongo, Bunkyo-ku, Tokyo, Japan

Tel:+81-3-5800-8657 E-mail: seisuke33tail@yahoo.co.jp

\section{Key words:}

Placental Insufficie ncy, fetal growth restriction, erythrocytes, hypoxia inducible factor 1-a (HIF-1a), amino acid transporter, large neutral amino acid transporter 1 (LAT1)

\begin{abstract}
:
Background: Insufficient oxygen supply is closely associated with the pathophysiology of fetal growth restriction (FGR). Although the erythrocyte is the most abundant and only cell type to deliver oxygen in our body, its function and regulatory mechanism in FGR remains unknown. Recently, intracellular adenosine uptake by equilibrative nucleoside transporter 1 (ENT1), a key adenosine transporter predominantly expressed in erythrocytes, was reported to be crucial for erythrocytes to deliver oxygen. Current study was aimed to investigate the involvement of erythrocytes' oxygen delivering capacity in maintaining fetal growth by focusing on erythrocyte ENT1.

Methods and Results: Conditional knockout mice with erythrocyte-specific gene deletion of ENT1 were utilized in this study. These mice indeed showed reduction in oxygen delivering capacity during pregnancy compared to control mice. We found that genetic ablation of mouse erythrocyte ENT 1 in dams results in FGR without showing any maternal features of preeclampsia. Unbiased highthroughput metabolic profiling led us to discover that these transgenic mice have lower amino acid concentration in the placenta and higher amino acid concentration in the serum compared to the control dams. Mechanistically and functionally, we revealed genetic ablation of maternal erythrocyte


ENT1 increases placental HIF - $1 \alpha$, preferentially reduces placental large neutral amino acid (AA) transporter 1(LAT1) expression and activity, and results in FGR. Translationally, we revealed elevated HIF - $1 \alpha$ directly reduces LAT1 gene expression in cultured human trophoblasts.

Conclusion: Our findings suggest that maternal erythrocytes'oxygen delivering capacity mediated by ENT1 is essential for maintaining adequate placental oxygenation to support fetal growth. Strategies to improve erythrocytes' function to deliver oxygen may provide new therapeutic possibilities for FGR. 